\title{
Antifungal activity of triterpenoid isolated from Azima tetracantha leaves
}

\section{Duraipandiyan'，M. Gnanasekar'2，S. Ignacimuthu1 ${ }^{1}$}

${ }^{1}$ Division of Ethnopharmacology, Entomology Research Institute, Loyola College, Chennai-34, India

2Piramal Healthcare Ltd, Chennai, India

\begin{abstract}
The present study was designed to evaluate the antifungal activity of Azima tetracantha extracts and isolated compound (friedelin) against fungi. Antifungal activity was carried out using broth microdilution method and fractions were collected using (silica gel) column chromatography. The antifungal activity of Azima tetracantha crude extracts and isolated compound (friedelin) were evaluated using the micro dilution method. Hexane extract showed some antifungal activity. The compound also exhibited antifungal activity against tested fungi. The lowest MIC against Trichophyton rubrum (296) was $62.5 \mu \mathrm{g} / \mathrm{ml}$ and the MIC for Curvularia lunata was $62.5 \mu \mathrm{g} / \mathrm{ml}$. These results suggest that Friedelin is a promising antifungal agent.
\end{abstract}

Key words: antibacterial, antifungal activity, Azima tetracantha, friedelin, Dermatophytes, Minimum Inhibitory Concentration, MIC

\section{Introduction}

Plants are still widely used for ethno medicine around the world and phytomedicines derived from plants have shown great promise in the treatment of intractable infectious diseases including those caused by opportunistic pathogens [1]. Microorganisms have been developing resistance to many antibiotics due to the indiscriminate use of antimicrobial drugs, increasing clinical problems in the treatment of infections. For example, the effectiveness of an antibiotic, ketoconazole, showed poor response in immuno-suppressed patients and in the treatment of meningitis [2].

Many of the plants used today were known to the people of ancient cultures throughout the world and they were valued for their preservative and medicinal powers. Scientific experiments on the antimicrobial properties of plants and their components have been documented in the late 19th century [3]. Plants have been shown to contain low molecular weight compounds which inhibit the growth of fungi in vitro.

Azima tetracantha (Salvadoraceae) is known as 'Mulsangu' in Tamil and 'Kundali' in Sanskrit, respec-

Correspondence: S. Ignacimuthu, Division of

Ethnopharmacology, Entomology Research Institute,

Loyola College, Chennai-34, India; tel.: (+9144) 28174644,

e-mail: entolc@hotmail.com tively. Its root, root bark and leaves are used with food as a remedy for rheumatism [4]. It is a powerful diuretic given in rheumatism, dropsy, dyspepsia and chronic diarrhoea and as a stimulant tonic after confinement [5]. Azima tetracantha as efficient acute phase antiinflammatory drug is traditionally used by Indian medical practitioners [6]. Azima tetracantha is used to treat cough, phthisis, asthma, small pox and diarrhea. The decoction of the stem bark is considered astringent, expectorant and antiperiodic [7-9].

Its leaves were found to possess azimine, azecarpin, carpine and isorhamnitine-3-O-rutinoside $[10,11]$. Friedelin, lupeol, glutinol and $\beta$-sitosterol have been isolated from the leaves of $A$. tetracantha [12]. Recently some novel fatty acids were isolated from seeds of this plant [13] .Plant extracts and essential oils show antifungal activity against wide range of fungi [14]. The current study was focused on the antifungal activity of hexane, ethyl acetate, methanol extracts and isolated compound (Friedelin) from Azima tetracantha leaves against dermatophytes responsible for infection of keratinized tissue and Candida albicans.

\section{Materials and methods}

Plant collection. A. tetracantha leaves were collected in the month of February from Kalvarayan hills, (altitude, 200 m), Tamil Nadu, 
South India. The plant was identified by authenticated botanist. A voucher specimen (ERI-569) has been deposited in Entomology Research Institute, Loyola College, Chennai, India.

Extraction and isolation. Leaves of Azima tetracantha were dried at room temperature and powdered by using electric blender $(500$ g). The dried powder was extracted with hexane by cold percolation for a period of 42 hours. The solvent was removed under reduced pressure using rotary evaporator; it gave $40 \mathrm{~g}$ of crude extract. This residue was dark black while subsequent extractions with more polar solvents (ethyl acetate and methanol) gave considerably dark brown residues. Hexane extract (20 g) was subjected to an initial separation on silica gel (acme's 100-200) using a short glass column $(7.4 \mathrm{~cm})$ and eluted with n-hexane and ethylacetate. Twenty five fractions were collected each having $100 \mathrm{ml}$. The fraction 13 and 14 were eluted by using hexane/ethyl acetate (95:5); it yielded $1.20 \mathrm{~g}$ of white powder. This showed three spots on TLC (Thin layer Chromatography); this was further fractionated using small silica gel column $(3.2 \mathrm{~cm})$. Initially $25 \mathrm{ml}$ fractions (1-25) were collected and subsequently increased to $50 \mathrm{ml}(25-44)$. Fraction 18 gave $90 \mathrm{mg}$ of needle like substance which was separated using hexane-ethyl acetate (90:10) as eluents.

Instruments. The structure of the isolated compound was identified by nuclear magnetic resonance (AL-300 JEOL) using, ${ }^{1} \mathrm{H}-$ NMR (300 MHz), ${ }^{13} \mathrm{C}-\mathrm{NMR}(75.45 \mathrm{MHz})$ analysis. IR spectrum was recorded in Shimadzu by $\mathrm{KBr}$ pellet method. Mass spectrometric analysis was conducted at the Mass Spectrometry, Shimadzu with temperature of EI method, Piramal Healthcare Ltd, Chennai, India.

Preparation of sample for testing. Crude extracts and Friedelin were dissolved in 5\% dimethyl sulfoxide (DMSO). For minimum inhibitory concentration (MIC) tests, extracts and compound first diluted to the highest concentration and then serial twofold dilutions were performed in a concentration range from $16.2 \mu \mathrm{g} / \mathrm{ml}$ to $1000 \mu \mathrm{g} / \mathrm{ml}$ for extract and $3.9 \mu \mathrm{g} / \mathrm{ml}$ to $250 \mu \mathrm{g} / \mathrm{ml}$ for compound in 96 well titrate plate containing Mueller-Hinton Broth. Preexperimental procedures demonstrated that final DMSO concentration below $5 \%$ did not inhibit microorganism growth.

Microorganism. Fungi, Trichophyton rubrum MTCC 296, T. rubrum 57/01, T.mentagrophytes 66/01, T. simii 110/02, Epidermophyton floccosum 73/01, Scopulariopsis sp. 101/01 Aspergillus niger MTCC 1344, Botyritis cinerea, Curvularia lunata 46/01 and Candida albicans MTCC 227 were used for the experiment. All the cultures were obtained from Madras Medical College, Chennai, India.

Preparation of inoculums. The filamentous fungi were grown on Sabouraud Dextrose Agar (SDA) slants at $28^{\circ} \mathrm{C}$ for 10 days and the spores were collected using sterile doubled distilled water and homogenized. Yeast was grown on Sabouraud Dextrose Broth (SDB) at $28^{\circ} \mathrm{C}$ for $48 \mathrm{~h}$.

Antifungal assay. The antifungal assay was performed according to standard Broth microdilution method [15]. MHB (Mueller Hinton Broth) was prepared and sterilized by autoclaving at $121^{\circ} \mathrm{C}, 15$ $\mathrm{lbs}$ for 15 minutes. The required concentrations of the extract $(15.62,31.25,62.5,125,250,500$ and $1000 \mu \mathrm{g} / \mathrm{ml})$ and compound $(3.90,7.81,15.62,31.25,62.5,125$ and $250 \mu \mathrm{g} / \mathrm{ml})$ were added to the 96 well micro titer plate containing $0.1 \mathrm{ml}$ broth. $5 \mu \mathrm{l}$ of $\log$ phase culture was introduced into the respective wells and the final inoculum size was $1 \times 10^{4} \mathrm{cfu} / \mathrm{ml}$ of fungal spore. The plate was covered and incubated at $27^{\circ} \mathrm{C}$ for $72-98$ hours for fungi. Appropriate controls included solvent controls that were used to dissolve the test compound, broth alone and the standard antibiotics: ketoconazole and fluconazole. Three replications were maintained.
After incubation period the MIC for fungi was defined as the lowest drug concentrations that inhibited visible growth of the fungi in 96 well plates. The results were evaluated by comparing them with control wells.

\section{Results and discussion}

Traditionally, Azima tetracantha has been used to treat many diseases. Hexane, ethyl acetate and methanol extracts were tested against fungi. Hexane extract showed some activity against tested fungi. The results are presented in table 1. Hexane extract was inhibiting the growth of Trichophyton rubrum 296, T. simii, E. floccosum, A. niger and Curvularia lunata at 62.5 $\mu \mathrm{g} / \mathrm{ml}$. Growth of T. rubrum 57/01 and Magnethopo$r a \mathrm{sp}$ were moderately inhibited at $250 \mu \mathrm{g} / \mathrm{ml}$. However it was ineffective against bacteria. Ethyl acetate extract inhibited the growth of T. rubrum 296 and A. niger at $62.5 \mu \mathrm{g} / \mathrm{ml}$. The lowest MIC values observed in hexane extract against T. simii, T. rubrum 296, E. floccosum, A. niger and C. lunata was $62.5 \mu \mathrm{g} / \mathrm{ml}$. Methanol extract inhibited the growth of $T$. rubrum $57 / 01$ at $1000 \mu \mathrm{g} / \mathrm{ml}$, E. floccosum at $500 \mu \mathrm{g} / \mathrm{ml}$ and $A$. niger at $500 \mu \mathrm{g} / \mathrm{ml}$. All the three extracts were not inhibiting the growth of Scopulariopsis sp. and C. albicans (Table 1).

Based on the screening results we selected the hexane extract for fractionation. Totally 25 fractions were collected and screened against fungi (Data were not shown). Further the active fraction was re-chromatographed and a compound was obtained from fraction 18. The isolated compound was crystallized using hexane: ethyl acetate mixture; it was colorless needle (yield $90 \mathrm{mg}$, m.p $263-265^{\circ} \mathrm{C}$ ). It answered Naller's test (Thionyl chloride gave pink colour). The isolated compound was confirmed as Friedelin by comparison with authentic sample (m.p, mm.p, super imposable IR and ${ }^{1} \mathrm{H}$ NMR, ${ }^{13} \mathrm{C}-\mathrm{NMR}$ and MASS spectral data) and our results compared satisfactorily with those reported in the literature [16]. The compound inhibited the growth of fungi such as T. rubrum 296 (62.5 $\mu \mathrm{g} / \mathrm{ml})$, C. lunata $(62.5 \mu \mathrm{g} / \mathrm{ml})$, T. simii $(125 \mu \mathrm{g} / \mathrm{ml})$ E. floccosum $(125 \mu \mathrm{g} / \mathrm{ml})$ A. niger $(125 \mu \mathrm{g} / \mathrm{ml})$ and Magnethophora sp (125 $\mu \mathrm{g} / \mathrm{ml})$ (Table 1). The lowest MIC values were observed against $C$. lunata and $T$. simii at $62.5 \mu \mathrm{g} / \mathrm{ml}$.

Vasanth et al [17] reported that friedelin isolated from hexane extract of Notonia grandiflora showed activity against Proteus mirabilis at 1000 ppm concentration.

Friedelin isolated from methanolic extract of Vismia laurentii. Fridelin was found to be the most active compound. The lowest minimum inhibition concentration (MIC) values as obtained by the micro-dilution assays were 19.53 and $1.22 \mu \mathrm{g} / \mathrm{ml}$ for the crude extracts and purified compounds, respectively [18].

Friedelin was also tested against bacteria but did 
Table 1. Antifungal activity of Azima tetracantha crude extracts and isolated compound friedelin. (-) - no activity, MIC of $<100 \mu \mathrm{g} / \mathrm{ml}$ - good activity, MIC of 100 to $500 \mu \mathrm{g} / \mathrm{ml}$ - moderate activity, MIC of $>1000 \mu \mathrm{g} / \mathrm{ml}$ - inactive.

\begin{tabular}{|c|c|c|c|c|c|c|}
\hline \multirow[t]{2}{*}{ Microorganism tested } & \multicolumn{3}{|c|}{$\begin{array}{l}\text { Crude extracts } \\
\qquad \mu \mathrm{g} / \mathrm{ml}]\end{array}$} & \multirow{2}{*}{$\begin{array}{l}\text { Friedelin } \\
\lfloor\mu \mathrm{g} / \mathrm{ml}\rfloor\end{array}$} & \multicolumn{2}{|c|}{$\begin{array}{c}\text { Antibiotic MIC } \\
{[\mu \mathrm{g} / \mathrm{ml}]}\end{array}$} \\
\hline & hexane & ethyl acetate & methanol & & fluconazole & ketoconazole \\
\hline T.mentagrophytes & 1000 & 1000 & $>1000$ & $>250$ & 25 & $<12.5$ \\
\hline T. simii & 62.5 & $>1000$ & $>1000$ & 125 & $<12.5$ & $<12.5$ \\
\hline Trichophyton rubrum 296 & 62.5 & 62.5 & $>1000$ & 62.5 & $<12.5$ & $<12.5$ \\
\hline T. rubrum 57/01 & 250 & $>1000$ & 1000 & $>250$ & 25 & $<12.5$ \\
\hline Epidermophyton floccosum & 62.5 & $>1000$ & 500 & 125 & 12.5 & $<12.5$ \\
\hline Scopulariopsis sp. & $>1000$ & $>1000$ & $>1000$ & $>250$ & $<12.5$ & $<12.5$ \\
\hline Aspergillus niger & 62.5 & 62.5 & 500 & 125 & 100 & $<12.5$ \\
\hline Curvularia lunata & 62.5 & 500 & $>1000$ & 62.5 & $<12.5$ & 12.5 \\
\hline Magnethophora sp. & 250 & $>1000$ & $>1000$ & 125 & - & - \\
\hline Candida albicans & $>1000$ & $>1000$ & $>1000$ & $>250$ & $>100$ & 25 \\
\hline
\end{tabular}

not show activity (data not shown). Pretto et al. [19] reported that friedelin was isolated from Calophyllum brasiliense and tested against Gram-positive and Gram-negative bacteria at $1000 \mu \mathrm{g} / \mathrm{ml}$. The compound was ineffective.

A thorough analysis of the results indicated that among the extracts of Azima tetracantha only the hexane extract showed some antifungal activity against tested fungi. A pure compound identified as Friedelin was isolated from the active hexane extract which exhibited antifungal activity. The compound and extracts possessed good antifungal activity in vitro and can be considered as potential candidate drug in the treatment of infectious diseases caused by pathogenic fungi.

\section{References}

[1] Maurice M, Iwu Angela R, Duncan C et al. New Antimicrobials of Plant Origin. Perspectives on new crops and new uses. J. Janick (ed.), ASHS Press, Alexandria, VA. 1999.

[2] Craven PC, Graybill JR. Combination of oral ucytosine and ketoconazole as therapy for experimental cryptococcal meningitis. J Infect Dis. 1984;149:584-590.

[3] Zaika LL. Species and herbs: their antimicrobial activity and its determination. J Food Safety. 1975;9:97-118.

[4] Kirtikar KR, Basu BD, An ICS. Indian Medicinal Plants, Vol. 1 and 2, 2nd Edn. Bishen Singh Mahendra Pal Singh, Dehra Dun. 1984;582:1541.

[ 5] Nadkarni KM. Indian Meteria Medica, Vol. 1, $3^{\text {rd }}$ Edn. Popular Prakhasan, Bombay. 1976;165:1089.

[6] Ismail TS, Gopalakrishnan S, Begum VH et al. Anti-inflammatory activity of Salacia oblonga Wall. and Azima tetracantha Lam. J Ethnopharmacol. 1997;56:145-152.

[7] Chelladurai V. Minnikizhangu- An unique folk medicinal plant from the adivasis (tribals) of point Calimere, Tamil Nadu. Bull Med Ethnobot Res. 1983;4:148-153.

[ 8] Kapoor SL, Kapoor LD. Medicinal plants wealth of karimna- gar district of Andhra Pradesh. Bull Med Ethnobot Res. 1980;1:120-247.

[ 9] Reddy MB, Reddy KR, Reddy MN. Ethnobotany of Cuddapah distirict ,Andhra Predesh, India. Int $J$ Pharmacog. 1991;29:273-280.

[10] Rail GJH, Smalberger TM, De Waal HL et al. Dimeric piperidine alkaloids from Azima tetracantha. Tetrahedron Lett. 1967;3465-3469.

[11] Williams UV, Nagarajan S. Isorhamnetin-3-O- rutinoside from leaves of Azima tetracantha Lain. Ind $J$ Chem. 1988;27:387.

[12] Rao VE, Prasada Rao PRS. Occurrence of triterpenoids in Azima tetracantha. Curr Sci. 1978;47:857.

[13] Daulatabad CD, Desai VA, Hosamani KM et al. Novel fatty acids in Azima tetracantha seed oil. J Am Oil Chem Soc. 1991;68:978-979.

[14] Kurita N, Makoto M, Kurane R et al. Antifungal activity of components of essential oils. Agric Biol Chem. 1981;45:945952.

[15] National Committee for Clinical Laboratory Standards. 2002. Reference method for broth dilution antifungal susceptibility testing of filamentous fungi. Approved standard M38-A. National Committee for Clinical Laboratory Standards, Wayne, $\mathrm{Pa}$.

[16] Ali MS, Mahmud S, Perveen S et al. Epimers from the leaves of Callophyllum inophyllum. Phytochemistry. 1999;50:13851389.

[17] Vasanth S, Govindarajan S, Raj MK. Antimicrobial activity of Notania grandiflora DC (Asteraceae). Ind J Pharm Sci. 2001;63:244-5

[18] Kuetea V, Nguemevingb JR, Benga VP et al. Antimicrobial activity of the methanolic extracts and compounds from Vismia laurentii De Wild (Guttiferae). J Ethnopharmacol. 2007; 109:372-379.

[19] Pretto JB, Filho V C, Noldin VF et al. Antimicrobial Activity of Fractions and Compounds from Calophyllum brasiliense (Clusiaceae/Guttiferae) Z. Naturforsch. 2004;59c:657-662.

Submitted: 30 June, 2009 Accepted after reviews: 11 February, 2010 